\title{
Effect of Three Harvest Intervals on Yield and Nutritive Value of Seven Napiergrass Cultivars ${ }^{1}$
}

\author{
J. Vélez-Santiago and J. A. Arroyo-Aguilü ${ }^{2}$
}

ABSTRACT

\begin{abstract}
Seven Napier or elephant grass cultivars (Pennisetum purpureum Schum.) were evaluated at the University of Puerto Rico Corozal Agricultural Experiment Substation for 2 years to measure the effect of 30-, 45-, and 60-day harvest intervals on green forage (GF), dry forage (DF), and crude protein (CP) yields, leaf/stem ratio, and chemical composition.

As the grasses advanced in maturity from 30 to 45 and from 45 to 60 days, GF, DF, and CP yields increased in all cultivars. Significant $(P<.05)$ differences occurred among cultivars as to GF, DF, and CP yields during the 2-year period. The highest DF yields were obtained by cultivars $13079,13078,7353$, and 7350. Significant $(\mathbb{P}<.05)$ differences also occurred among cultivars as to GF and DF yields during the short-day and dry-month periods of the year. Leaf/stem ratio was higher during the short-day and dry-month periods, and lower during heavy rainfall periods. At the 45-day harvest interval, cultivar 13079 was highest in neutral-detergent fiber, acid-detergent fiber, and lignin contents, but lowest in CP and estimated digestibility contents.
\end{abstract}

\section{INTRODUCTION}

Many dairymen utilize Napier or elephant grass (Pennisetum purpureum Schum.) as soilage for cattle feeding in Puerto Rico. The variety Merker has been exclusively used due to its high yield, aggressiveness, persistence, and ability to compete with weeds under intensive fertilizer management. This grass is generally harvested every 50 to 60 days when its yield and nutritive value are rather high (15).

Napier grass has been thoroughly studied in Puerto Rico and other countries $(1,2,3,10,14,15,17,19,20,21,22)$. Caro-Costas et al. (5) in Puerto Rico and Takahashi (18) in Hawaii reported excellent performance of this grass under grazing management. In 1954, Boneta-García (4) compared green forage (GF) yields of 6 Pennisetum cultivars at 3 different regions of Puerto Rico. Comparative cutting trials of elephant grass varieties were reported in other countries by Delgado et al. (6), GarridoVirguez (7), Pereira et al. (11) and Zuñiga et al. (24).

This study was conducted in order to compare the yield of 6 Pennisetum purpureum cultivars with that of cultivar Merker at 30-, 45-, and 60day harvest intervals in the humid mountainous region of Puerto Rico. Criteria considered were total and seasonal GF and dry forage (DF) yields, chemical composition, crude protein (CP) yields, leaf/stem ratio,

\footnotetext{
${ }^{1}$ Manuscript submitted to Editorial Board February 21, 1980

${ }^{2}$ Associate Agronomist, Corozal Substation, and Nutritionist, Animal Industry Department. Agricultural Experiment Station, Mayagüez Campus, University of Puerto Rico, Río Piedras, P. R., respectively.
} 
and estimated digestible (EDDM), true (ETDDM), and apparent (EADDM) digestible dry matter values of the 7 cultivars.

\section{MATERIALS AND METHODS}

The experiment was conducted over a 2-year period (January 1975 to January 1977) at the Corozal Agricultural Experiment Substation on a Corozal clay of the sub-group Aquic Tropudults (Ultisol), with phosphorus $(\mathrm{P})$, potassium $(\mathrm{K})$, and magnesium $(\mathrm{Mg})$ contents of $2.5,196$, and 3.1 $\mathrm{p} / \mathrm{m}$ at the level of $20 \mathrm{~cm}$ of soil, respectively. Calcium carbonate was applied 2 months before planting to raise the $\mathrm{pH}$ from 4.8 to approximately 6.0 (12). After the first year, the soil was limed to a sustained $\mathrm{pH}$ of 6.0 .

The following tabulation shows the identification of the 7 cultivars.

$\begin{array}{ccc}\text { USDA } \mathrm{PI}^{3} & P R P I^{4} & \text { Other } \\ - & 7350 & - \\ 285303 & 13079 & - \\ 300086 & 13078 & - \\ - & 7353 & - \\ - & - & \text { Merker } \\ 337620 & 11720 & - \\ - & - & \text { I-12 }\end{array}$

Three-month-old mature cuttings (3-bud pieces) were planted per row, with the double cane per row method. The experimental design was a randomized split plot, with the cultivars as main plots, each replicated 4 times, and 30-, 45-, and 60-day harvest intervals as the sub-plots. Main plots were $7.32 \times 6.96 \mathrm{~m}$ and sub-plots $2.44 \times 6.96 \mathrm{~m}$. Sub-plots consisted of 4 rows $0.61 \mathrm{~m}$ apart. A 1.22 -m alley was left between main plots.

All plots were fertilized at a rate of $4,484 \mathrm{~kg} / \mathrm{ha} / \mathrm{yr}$ with a commercial formula, analysis 15-5-10. The total annual fertilizer was divided into 12, 8, and 6 equal applications for 30-, 45-, and 60-day harvest intervals, respectively, and the corresponding amount applied after each harvest. All cultivars were harvested at approximately 5 -cm height above the ground. The forage was weighed, sampled, dried at $60^{\circ} \mathrm{C}$, and ground in a Wiley ${ }^{5}$ mill to pass through a 1-mm screen.

The mean annual temperature during the 2 years was $76.0^{\circ} \mathrm{C}, 90.8^{\circ} \mathrm{C}$ maximum and $67.8^{\circ} \mathrm{C}$ minimum. During the first and second years, rainfall totalled 1,389 and $1,390 \mathrm{~mm}$, respectively. The plots were not irrigated.

${ }^{3}$ United States Department of Agriculture plant introduction number.

${ }^{4}$ University of Puerto Rico Agricultural Experiment Station plant introduction number.

${ }^{5}$ Trade names in this publication are used only to provide specific information. Mention of a trade name does not constitute a warranty of equipment or materials by the Agricultural Experiment Station of the University of Puerto Rico, nor is this mention a statement of preference over other equipment or materials. 
DM was determined in all samples. For each harvest interval, samples were composited by replications. Each treatment was analyzed for total nitrogen $(\mathrm{N})$ with a Technicon auto-analyzer and for $\mathrm{P}$ and $\mathrm{K}$ by the method of foliar diagnosis (13). $\mathrm{CP}$ was calculated as $\mathrm{N} \times 6.25$. Fortyfive-day samples were analyzed for neutral-detergent fiber (NDF), aciddetergent fiber (ADF), lignin (L), and silica (Si) (8). Neutral-detergent soluble (NDS) content was calculated as the difference between 100 and NDF. Hemicellulose content was calculated as the difference between NDF and ADF. Digestibility values were calculated from Goering and Van Soest's summative equation (8):

$\%$ estimated digestible dry matter $=0.98(\% \mathrm{NDS})+\% \mathrm{NDF}\left[180.8-96.6 \log _{10}(\% \mathrm{~L} / \% \mathrm{ADF}) 100\right]$,

$\%$ estimated true digestible dry matter $=0.98(\% \mathrm{NDS})+\% \mathrm{NDF}\left[180.8-96.6 \log _{10}(\% \mathrm{~L} / \% \mathrm{ADF}) 100\right]-$ $3.0(\% \mathrm{Si})$,

$\%$ estimated apparent digestible dry matter

$=0.98(\% \mathrm{NDS})+\%$ NDF $\left[180.8-96.6 \log _{10}(\% \mathrm{~L} / \% \mathrm{ADF}) 100\right]-$ $3.0(\% \mathrm{Si})-12.9$

Leaf/stem ratio was measured for the 45- and 60-day harvests in the second year. Before each harvest, 30 canes were taken at random for leaf/ stem determinations.

The 2-year data for GF, DF, and CP yields and for DM and CP contents were subjected to variance analysis, with Duncan's multiple range test (16). A particular analysis was conducted in order to compare the DF yields at 45- and 60-day harvest intervals during the short-cool days of the year.

\section{RESULTS AND DISCUSSIONS}

Table 1 and figure 1 show mean GF, DF and CP yields and DM and $\mathrm{CP}$ contents of the 7 cultivars at the 30-, 45-, and 60-day harvest intervals during the 2-year period. At the 30-day harvest interval, the most productive as to GF, DF, and CP yields were cultivars 7350, 13079, 13078, 7353, and Merker. The least productive were cultivars 11720 and I-12. Cultivars I-12 and 11720 were lowest in DM but highest in CP content.

At the 60-day harvest interval, cultivars 13078, 7350, and 13079 produced the highest GF yields and outyielded significantly $(\mathrm{P}<.05)$ cultivars I-12, Merker, and 11720 (table 1). Highest DF yielders were cultivars $13078,13079,7350$, and 7353 . These were significantly $(\mathrm{P}<.05)$ different from cultivars Merker, I-12, and 11720.

Table 2 shows the mean values for GF, DF and CP yields and for DM, $\mathrm{CP}, \mathrm{P}$, and $\mathrm{K}$ contents for the 7 grasses. GF, DF, and $\mathrm{CP}$ mean yields increased significantly $(P<.05)$ as harvest intervals increased from 30 to 
45 and from 45 to 60 days. For DM content, significant differences ( $\mathrm{P}<$ .05 ) were obtained only between 30 or 45 days and 60 days. CP content was significantly $(\mathrm{P}<.05)$ reduced from 30 to 45 days and from 45 to 60 days. Phosphorus and $\mathrm{K}$ contents diminished as harvest intervals increased. These values can be considered as normal, as reported by Vicente-Chandler et al. (20), and demonstrate that growth was not limited by these minerals.

TABLE 1.-Effect of harvest interval on the mean green forage, dry forage, and crude protein yields and on the dry matter and crude protein contents of 7 Pennisetum cultivars at 3 harvest intervals

\begin{tabular}{|c|c|c|c|c|c|}
\hline $\begin{array}{l}\text { Identifi- } \\
\text { cation }\end{array}$ & $\begin{array}{l}\text { Green forage } \\
\text { yield }^{1}\end{array}$ & $\begin{array}{l}\text { Dry } \\
\text { matter } \\
\text { content }\end{array}$ & $\begin{array}{l}\text { Dry forage } \\
\text { yield }\end{array}$ & $\begin{array}{l}\text { Crude } \\
\text { protein } \\
\text { content }\end{array}$ & $\begin{array}{c}\text { Crude } \\
\text { protein } \\
\text { yield }\end{array}$ \\
\hline & $\mathrm{Kg} / \mathrm{ha} / \mathrm{y}$ & $\%$ & $K g / h a / y$ & $\%$ & $\mathrm{Kg} / \mathrm{ha} / \mathrm{y}$ \\
\hline \multicolumn{6}{|c|}{ 30-day grasses } \\
\hline 7350 & $127,986 \mathrm{a}^{1}$ & 14.56 & $18,634 a$ & $14.67 \mathrm{c}$ & $2,723 a$ \\
\hline 13079 & $121,981 \mathrm{ab}$ & 15.32 & $18,684 \mathrm{a}$ & $14.23 \mathrm{c}$ & $2,667 \mathrm{a}$ \\
\hline 13078 & $117,379 a b$ & 14.54 & $17,074 \mathrm{a}$ & $14.16 \mathrm{c}$ & $2,438 \mathrm{ab}$ \\
\hline 7353 & $112,812 \mathrm{ab}$ & 14.57 & $16,437 \mathrm{a}$ & $15.80 \mathrm{~b}$ & $2,606 \mathrm{a}$ \\
\hline Merker & $92,979 \mathrm{abc}$ & 14.54 & $13,518 \mathrm{ab}$ & $16.73 \mathrm{ab}$ & 2,261abc \\
\hline 11720 & $72,035 \mathrm{bc}$ & 13.54 & $9,758 \mathrm{~b}$ & $17.42 \mathrm{a}$ & $1,676 \mathrm{bc}$ \\
\hline $\mathrm{I}-12$ & $58,695 \quad \mathrm{c}$ & 14.33 & $8,412 \mathrm{~b}$ & $17.86 \mathrm{a}$ & $1,498 \quad c$ \\
\hline \multicolumn{6}{|c|}{ 45-day grasses } \\
\hline 7350 & $182,671 \mathrm{ab}$ & 14.17 & 25,883 abcd & $11.42 \mathrm{~b}$ & $2,946 \mathrm{bc}$ \\
\hline 13079 & $210,642 \mathrm{a}$ & 15.49 & $32,634 \mathrm{a}$ & $11.36 \mathrm{~b}$ & $3,718 \mathrm{ab}$ \\
\hline 13078 & $202,194 a$ & 14.95 & $30,231 \mathrm{ab}$ & $11.47 \mathrm{~b}$ & $3,464 a b$ \\
\hline 7353 & $203,571 \mathrm{a}$ & 14.59 & $29,703 a b c$ & $13.12 \mathrm{a}$ & $3,897 \mathrm{a}$ \\
\hline Merker & $135,194 \mathrm{~b}$ & 14.84 & $20,071 \quad d$ & $12.90 \mathrm{a}$ & $2,606 \quad \mathrm{c}$ \\
\hline 11720 & $166,222 \mathrm{ab}$ & 13.95 & $23,185 \quad c d$ & $12.67 \mathrm{a}$ & $2,941 \mathrm{bc}$ \\
\hline $\mathrm{I}-12$ & $179,924 \mathrm{ab}$ & 14.28 & 25,690 bcd & $13.01 \mathrm{a}$ & $3,358 \mathrm{abc}$ \\
\hline \multicolumn{6}{|c|}{ 60-day grasses } \\
\hline 7350 & $303,342 \mathrm{a}$ & 17.52 & $53,167 a$ & $7.76 \quad \mathrm{c}$ & $4,150 \mathrm{ab}$ \\
\hline 13079 & $293,791 a$ & 18.60 & $54,640 \mathrm{a}$ & $7.99 \mathrm{bc}$ & $4,404 a b$ \\
\hline 13078 & $326,034 a$ & 17.49 & $57,038 \mathrm{a}$ & $8.09 \mathrm{bc}$ & $4,572 \mathrm{ab}$ \\
\hline 7353 & $274,589 \mathrm{ab}$ & 18.86 & $51,785 a$ & $9.12 \mathrm{ab}$ & $4,759 \mathrm{a}$ \\
\hline Merker & 234,340 b & 18.56 & $43,510 \mathrm{~b}$ & $8.84 \mathrm{abc}$ & $3,845 \mathrm{~b}$ \\
\hline 11720 & 234,040 b & 17.07 & $39,954 \mathrm{~b}$ & $9.48 \mathrm{a}$ & $3,787 \mathrm{~b}$ \\
\hline I -12 & $238,755 \mathrm{~b}$ & 17.62 & $42,081 \quad b$ & $9.36 \mathrm{a}$ & $3,950 \mathrm{ab}$ \\
\hline
\end{tabular}

${ }^{1}$ Means in the same column followed by one or more letters in common do not differ significantly at the 5-percent probability level.

Table 3 shows total GF and DF yields and DM content for 3 harvests from October 3, 1975, to February 17, 1976, for 45-day grasses, and from September 4, 1975, to March 3, 1976, for 60-day grasses. Cultivars 13078 and 13079 presented highest GF and DF yields at 45 days, significantly $(\mathrm{P}<.05)$ different from those of cultivar Merker. At 60 days, cultivar 13078 outyielded significantly $(P<.05)$ all other cultivars in GF. However, 


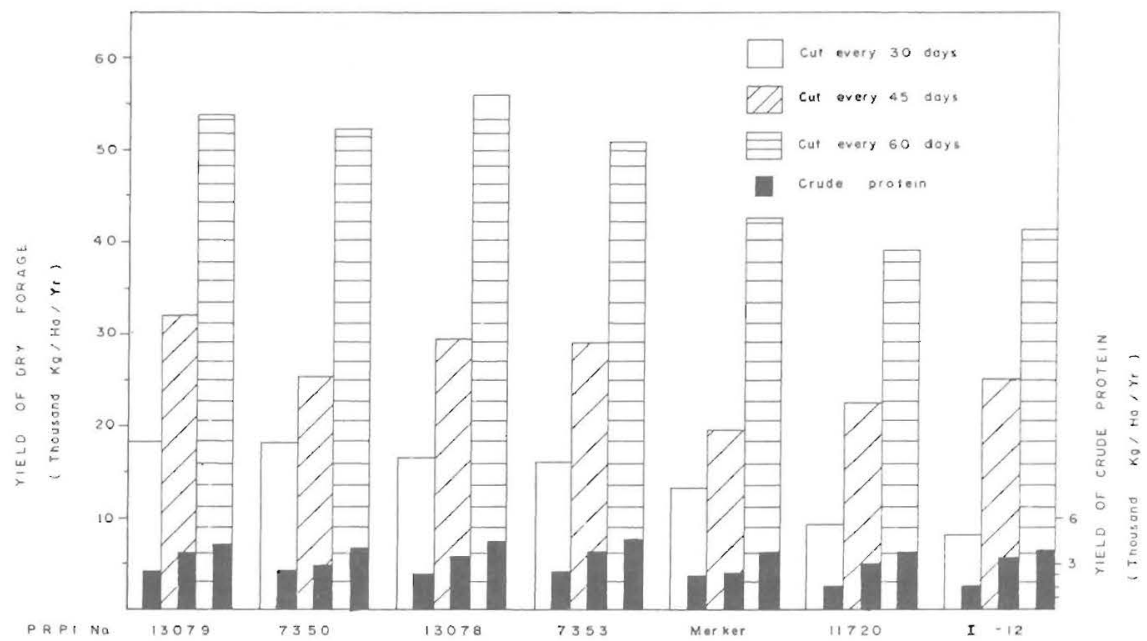

FIG. 1.-Dry forage and crude protein yields of seven Napiergrass cultivars at 30-, 45and 60-day harvest intervals.

TABLE 2.-Mean green forage, dry forage, and crude protein yields; and dry matter, crude protein, phosphorus, and potassium contents of 7 Pennisetum cultivars at 3 harvest intervals

\begin{tabular}{|c|c|c|c|c|}
\hline \multirow{2}{*}{ Item and unit of measurement } & \multicolumn{3}{|c|}{ Harvest interval (days) } & \multirow{2}{*}{ Mean } \\
\hline & 30 & 45 & 60 & \\
\hline $\begin{array}{l}\text { Green forage yield per ha per } \\
\text { year, kg }\end{array}$ & $100,552 \mathrm{c}^{1}$ & $182,917 \mathrm{~b}$ & $272,127 a^{2}$ & 185,199 \\
\hline Dry matter, percent & $14.49 \mathrm{~b}$ & $14.61 \mathrm{~b}$ & $17.96 \mathrm{a}$ & 15.69 \\
\hline $\begin{array}{l}\text { Dry forage yield per ha per year, } \\
\text { kg }\end{array}$ & $14,645 \mathrm{c}$ & $26,771 b$ & $48,882 \mathrm{a}$ & 30,099 \\
\hline Crude protein, percent & $15.84 \mathrm{a}$ & $12.28 \mathrm{~b}$ & $8.67 \mathrm{c}$ & 12.26 \\
\hline $\begin{array}{l}\text { Crude protein yield per ha per } \\
\text { year, kg }\end{array}$ & $2,267 \mathrm{c}$ & $3,276 \mathrm{~b}$ & $4,210 \mathrm{a}$ & 3,251 \\
\hline Phosphorus, percent & .32 & .29 & .23 & .28 \\
\hline Potassium, percent & 4.23 & 3.96 & 3.27 & 3.82 \\
\hline
\end{tabular}

${ }^{1}$ Means of 7 cultivars.

${ }^{2}$ Means in the same row followed by one or more letters in common do not differ significantly at the 5-percent probability level.

DF yields of cultivar 13078 and 13079 were significantly $(\mathrm{P}<.05)$ different f rom cultivars I-12, 11720, and Merker only.

Table 4 shows the leaf/stem ratio for the 7 cultivars at the 45 - and 60 day harvest intervals during 1976. At 45 days, high leaf/stem values corresponded to the period of low rainfall from May 18 to August 16, 1976. Also high leaf/stem values occurred during the short-day period from January 3 to February 16, 1976. Low leaf/stem values occurred 
TABLE 3.-Total green and dry forage yields and dry matter content for 3 harvests at 2 harvest intervals during the short-day and dry-month periods of 1975-76

\begin{tabular}{|c|c|c|c|}
\hline Identification & $\begin{array}{l}\text { Green forage } \\
\text { yield }^{1}\end{array}$ & $\begin{array}{l}\text { Dry matter } \\
\text { content }\end{array}$ & $\begin{array}{l}\text { Dry forage } \\
\text { yield }\end{array}$ \\
\hline & $\mathrm{Kg} / \mathrm{ha}$ & $\%$ & $\mathrm{Kg} / \mathrm{ha}$ \\
\hline \multicolumn{4}{|c|}{ 45-day grasses } \\
\hline 13078 & $120,447 \mathrm{a}^{1}$ & $13.10 \mathrm{bc}$ & $15,809 \mathrm{ab}$ \\
\hline 13079 & $119,248 \mathrm{a}$ & $14.95 \mathrm{a}$ & $17,790 \mathrm{a}$ \\
\hline I -12 & $102,555 \mathrm{ab}$ & $12.99 \quad \mathrm{c}$ & 13,341 bc \\
\hline 7353 & $97,038 \mathrm{ab}$ & $14.57 \mathrm{a}$ & $14,138 \mathrm{abc}$ \\
\hline 7350 & - $93,482 \mathrm{ab}$ & $13.55 \mathrm{bc}$ & $12,667 \mathrm{bc}$ \\
\hline 11720 & $93,299 a b$ & $12.94 \quad \mathrm{c}$ & $12,073 \mathrm{bc}$ \\
\hline Merker & $72,685 \mathrm{~b}$ & $14.10 \mathrm{ab}$ & $10,221 \quad \mathrm{c}$ \\
\hline \multicolumn{4}{|c|}{ 60-day grasses } \\
\hline 13078 & $199,166 \mathrm{a}$ & $14.97 \mathrm{c}$ & $29,667 \mathrm{a}$ \\
\hline 13079 & $163,332 \mathrm{~b}$ & $16.82 \mathrm{ab}$ & $27,472 \mathrm{a}$ \\
\hline I-12 & $135,047 \quad \mathrm{c}$ & $17.51 \mathrm{ab}$ & $23,652 \mathrm{~b}$ \\
\hline 7353 & $132,456 \quad \mathrm{c}$ & $19.50 \mathrm{a}$ & $25,847 a b$ \\
\hline 7350 & $149,372 \mathrm{bc}$ & $17.41 \mathrm{ab}$ & $26,006 \mathrm{ab}$ \\
\hline 11720 & $126,776 \quad \mathrm{c}$ & $16.98 \mathrm{ab}$ & $21,549 \mathrm{~b}$ \\
\hline Merker & $128,016 \quad \mathrm{c}$ & $18.38 \mathrm{ab}$ & $23,529 \mathrm{~b}$ \\
\hline
\end{tabular}

${ }^{1}$ Means in the same column followed by one or more letters in common do not differ significantly at the 5 -percent probability level.

TABLE 4.-Values for leaf/stem ratio (green weight) for the 7 Pennisetum cultivars at 45 and 60 days of growth and of rainfall per period

\begin{tabular}{|c|c|c|c|c|c|c|c|c|}
\hline \multirow{2}{*}{ Harvest date } & \multicolumn{7}{|c|}{ Leaf/stem ratio } & \multirow{2}{*}{$\begin{array}{l}\text { Rainfall } \\
\text { per } \\
\text { period }\end{array}$} \\
\hline & $\mathrm{I}-12$ & Merker & 7350 & 7353 & 11720 & 13078 & 13079 & \\
\hline & & & & & & & & $\mathrm{Cm}$ \\
\hline \multicolumn{9}{|c|}{ 45-day grasses } \\
\hline $1 / 3-2 / 16 / 76$ & .81 & .81 & .80 & .79 & .82 & .80 & .82 & 13.6 \\
\hline $2 / 17-4 / 2 / 76$ & .65 & .61 & .74 & .79 & .70 & .74 & .70 & 21.0 \\
\hline $4 / 3-5 / 17 / 76$ & .64 & .63 & .66 & .67 & .70 & .67 & .70 & 22.1 \\
\hline $5 / 18-7 / 1 / 76$ & .81 & .87 & .82 & .73 & .82 & .71 & .82 & 3.7 \\
\hline $7 / 2-8 / 16 / 76$ & .81 & .71 & .88 & .88 & .93 & .89 & .93 & 9.9 \\
\hline $8 / 17-10 / 4 / 76$ & .66 & .62 & .65 & .62 & .70 & .71 & .70 & 22.3 \\
\hline $10 / 5-11 / 14 / 76$ & .55 & .50 & .52 & .48 & .50 & .60 & .50 & 34.0 \\
\hline $11 / 15-1 / 3 / 77$ & .67 & .64 & .66 & .66 & .65 & .65 & .65 & 12.5 \\
\hline Mean & .70 & .67 & .72 & .70 & .73 & .72 & .73 & 17.4 \\
\hline \multicolumn{9}{|c|}{ 60-day grasses } \\
\hline $1 / 2-3 / 2 / 76$ & .71 & .66 & .65 & .71 & .71 & .81 & .71 & 21.7 \\
\hline $3 / 3-5 / 3 / 76$ & .63 & .58 & .60 & .64 & .66 & .63 & .60 & 28.6 \\
\hline $5 / 4-7 / 1 / 76$ & .49 & .55 & .61 & .61 & .61 & .63 & .68 & 10.0 \\
\hline $7 / 2-9 / 1 / 76$ & .61 & 62 & .64 & .63 & .67 & .72 & .73 & 13.0 \\
\hline $9 / 2-11 / 3 / 76$ & .47 & .43 & .31 & .38 & .41 & .51 & .53 & 51.0 \\
\hline $11 / 4-1 / 3 / 77$ & .58 & .48 & .41 & .47 & .59 & .67 & .41 & 14.6 \\
\hline Mean & .58 & .55 & .54 & .57 & .61 & .66 & .61 & 23.2 \\
\hline
\end{tabular}

${ }^{1}$ Mean values of 4 replicates per grass.

${ }^{2}$ Stem includes the sheath. 
during the period of maximum rainfall; i.e., from October 5 to November 14, 1976. A similar pattern for leaf/stem values was observed for the 60day harvest interval data. Increases or decreases in leaf/stem values of 13 elephant cultivars have been reported by Garrido-Virguez (7), with increases or decreases in the rainfall distribution throughout the year. Decreases have also been reported for leaf/stem ratios by Vicente-Chandler et al. (23), as harvest interval increases from 40 to 60 days.

At the 45-day harvest interval (tables 1 and 5), cultivar 13079 presented the highest NDF, ADF, and L contents but the lowest CP and estimated digestibility contents. Cultivar 7353 had the lowest L content but the highest estimated digestibility contents. As fiber fractions increase, CP and digestibility contents decrease. Forage grasses, with a higher fibrous content, tend to exhibit lower $\mathrm{CP}$ and digestibility contents. Kayongo-

TABLE 5.-Chemical composition and estimated digestibility values of 7 Pennisetum cultivars at 45 days of growth

\begin{tabular}{llcccccccc}
\hline $\begin{array}{c}\text { Identifica- } \\
\text { tion }\end{array}$ & NDF $^{1}$ & NDS & ADF & $\mathrm{H}$ & $\mathrm{L}$ & $\mathrm{Si}$ & EDDM & ETDDM & EADDM \\
\hline & & & & $\%$ & & & & & \\
I-12 & $67.90^{2}$ & 32.10 & 39.08 & 28.82 & 8.41 & 2.07 & 66.80 & 60.59 & 47.69 \\
Merker & 67.23 & 32.77 & 37.52 & 29.71 & 8.26 & 2.08 & 66.46 & 60.22 & 47.32 \\
7350 & 68.02 & 31.98 & 39.47 & 28.55 & 8.39 & 2.48 & 67.09 & 59.65 & 46.75 \\
7353 & 68.14 & 31.86 & 39.81 & 28.33 & 8.22 & 2.26 & 67.87 & 61.09 & 48.19 \\
11720 & 67.07 & 32.93 & 38.15 & 28.92 & 8.48 & 2.52 & 66.27 & 58.71 & 45.81 \\
13079 & 70.73 & 29.27 & 41.49 & 29.24 & 9.18 & 2.40 & 64.66 & 57.46 & 44.56 \\
13078 & 70.24 & 29.76 & 39.27 & 30.97 & 8.82 & 1.85 & 64.46 & 58.91 & 46.01 \\
Mean & 68.48 & 31.52 & 39.26 & 29.22 & 8.54 & 2.24 & 66.23 & 59.52 & 46.62 \\
\hline
\end{tabular}

${ }^{1} \mathrm{NDF}$, neutral-detergent fiber; NDS, neutral-detergent solubles; ADF, acid-detergent solubles; H, hemicellulose; L, lignin; Si, silica; EDDM, estimated digestible dry matter; ETDDM, estimated true digestible dry matter; EADDM, estimated apparent digestible dry matter.

${ }^{2}$ Means of 4 replicates per grass.

Male et al. (9) demonstrated that differences in chemical composition and estimated digestibility do exist among grasses grown under the same environmental and agronomic conditions. They obtained a significant variation among $\mathrm{CP}$ and fibrous contents (ADF and cellulose) in Pennisetum cultivars, suggesting that there may be a possibility of genetic improvement for tropical grasses.

After the first year, the stands of the 7 cultivars were greatly reduced on 30-day plots. This decrease suggests that the 30 -day harvest interval is too short. It was observed that the least affected plots, by frequent harvests, were those of cultivars 7350 and 7353.

During the rainy season, a high degree of infestation, caused by Piricularia grisea (CKe) Sacc., and known as gray spot disease, appeared on cultivars Merker, 11720, and I-12 harvested every 30 days. It was 
observed that cultivars 13078, 13079, 7350, and 7353 exhibited resistance to this disease.

It can be concluded that cultivars $7350,13079,13078$, and 7353 were the most productive as to GF, DM, and CP yields at the 30-, 45-, and 60day harvest intervals. Cultivars 13078 and 13079 outyielded cultivar Merker as to GF and DM during the short-day period from September 1975 to March 1976. These cultivars also showed a high degree of resistance to the gray spot disease during the rainy season. A 30-day harvest frequency is not recommended for stand persistency and survival.

\section{RESUMEN}

Se determinó el efecto de los intervalos de corte de 30, 45 y 60 días en los rendimientos de forraje verde, forraje seco y proteína bruta y en la razón de hoja a tallo y de composición química de siete cultivares del pasto elefante (Pennisetum purpureum Schum.) durante 2 años, en la Subestación Experimental de Corozal de la Universidad de Puerto Rico, que está localizada en la región húmeda montañosa de Puerto Rico.

Según se alargaron los intervalos de corte de 30 a 45 y de 45 a 60 días, los rendimientos de forraje verde, forraje seco y proteína bruta aumentaron en todos los cultivares. Se obtuvieron diferencias significativas $(P<.05)$ entre cultivares en los rendimientos de forraje verde, forraje seco y proteína bruta durante los 2 años del estudio. Los cultivares 7350, 7353, 13078 y 13079 presentaron los mayores rendimientos de forraje seco. Se obtuvieron también diferencias significativas ( $P$ $<.05$ ) entre cultivares en rendimientos de forraje verde y forraje seco durante los períodos de días cortos y meses secos. La razón de hoja a tallo fue mayor duante los períodos de días cortos y meses secos y menor durante el período de lluvia intensa. A los 45 días de crecimiento, el cultivar 13079 fue el máximo en contenidos de fibra neutrodetergente, fibra ácidodetergente y lignina y menor en proteína bruta y coeficientes de digestibilidad estimada.

\section{LITERATURE CITED}

1. Abruña, F., Vicente-Chandler, J., and Pearson, R. W., 1964. Effects of liming on yields and composition of heavily fertilized grasses and on soil properties under humid tropical conditions, Proc. Soil Sci. Soc. Am. 28 (5): 657-61.

2. Alexander, A. G. and Spain, G. L., 1970. Isolation and properties of Napier grass $\beta$ amylase, J. Agri. Univ. P. R. 54 (4): 640-56.

3. Bateman, J. V. and Decker, G., 1962. Production, analysis and acceptability by cattle of some varieties of elephant grass (Pennisetum purpureum Schum.), Trop. Agri. 39 (2): $133-40$.

4. Boneta-García, E., 1954. Nuevas yerbas forrajeras para Puerto Rico, Esta. Exp. Agri. Univ. P. R. Pub. Misc. 12.

5. Caro-Costas, R. and Vicente-Chandler, J., 1972. Effect of heavy rates of fertilization on beef production and carrying capacity of Napier grass pastures over 5 consecutive years of grazing under humid tropical conditions, J. Agri. Univ, P. R. 56 (3): 223-7. 
6. Delgado, E., Páez H., C. J., and Silva P., J. V., 1966. Frecuencia de corte en siete variedades de pasto elefante, Agri. Trop. 22 (10): 516-26.

7. Garrido-Virguez, O., 1965. Comparative trials of 13 clones of elephant grass (Pennisetum purpureum Schum.), Proc. 9th Inter. Grassland Cong. 929-38.

8. Goering, H. K. and Van Soest, P. J., 1970. Forage fiber analyses (apparatus, reagents, procedures and some applications, USDA Agri. Handbook 379.

9. Kayongo-Male, H., Thomas, J. W., Ullrey, D. E., Deans, R. J., and Arroyo-Aguilú, J. A., 1976. Chemical composition and digestibility of tropical grasses, J. Agri. Univ. P. R. 60 (2): $186-200$.

10. Oakes, A. J., 1959. Germination of elephant grass (Pennisetum purpureum Schum.), J. Agri. Univ. P. R. 43 (2): 140.

11. Pereira, R. M. A., Sykes, D. J., Gomide, J. A., and Vidigal, G. T., 1965. Competição de 10 gramineas para capineiras, no cerrado, em 1965, Rv. Ceres 13 (74): 141-53.

12. Riera, A., 1946. A laboratory recommendation of lime to an acid soil checks with expected pH changes, J. Agri. Univ. P. R. 30 (3): 184-5.

13. _- 1955. The method of foliar diagnosis as applied to sugarcane, II, The chemical analyses of sugarcane-leaf samples, Univ. P. R. Agri. Exp. Stn. Bull. 123.

14. Rivera-Brenes, L., Cestero, H., and Sierra, A., 1962. Napier grass (Pennisetum purpureum) versus (Saccharum officinarum) as forage crops in Puerto Rico, J. Agri. Univ. P. R. 46 (4): 307-12.

15. - - Arroyo, J. A., Cestero, H., and Sierra, A., 1961. Palatability tests on giant Pangola (Digitaria valida Stent) and Signal grass (Brachiaria brizantha) as compared with Napier (Merker) grass (Pennisetum purpureum), J. Agri. Univ. P. R. 45 (3): 147-50.

16. Snedecor, G. W. and Cochran, W. G., 1967. Statistical methods, 6th ed, The Iowa State Univ. Press, Ames, Iowa.

17. Spain, G. L. and Vélez-Santiago, J., 1973. Napier grass harvest readiness, J. Agri. Univ. P. R. 57 (4): 300-6.

18. Takahashi, M., Moomaw, J. C., and Ripperton, J. C., 1966. Studies of Napier grass, III, Grazing management, Hawaii, Agri. Exp. Stn. Bull. 128.

19. Vicente-Chandler, J. and Figarella, J., 1962. Effects of five nitrogen sources on yield and composition of Napier grass, J. Agri. Univ. P. R. 46 (2): 102-6.

20. - - Silva, S., and Figarella, J., 1959. Effects of nitrogen fertilization and frequency of cutting on the yield and composition of Napier grass (Pennisetum purpureum Schum.) in Puerto Rico, J. Agri. Univ. P. R. 43 (4): 215-27.

21. — - -, and - -1959 . The effect of nitrogen fertilization and frequency of cutting on the yield and composition of three tropical grasses, Agron. J. 51 (4): 202-6.

22. - - Pearson, R. W., Abruña, F., and Silva, S., 1962. Potassium fertilization of intensively managed grasses under humid tropical conditions, Agron. J. 54 (5): 450-3.

23. —- Abruña, F., Caro-Costas, R., Figarella, J., Silva, S., and Pearson, R. W., 1974. Intensive Grassland Management in the Humid Tropies of Puerto Rico, Agri. Exp. Stn. Univ. P. R., Bull. 233.

24. Zuñiga, M. P., Sykes, D. J., and Gomide, J. A., 1967. Competição de treze gramíneas forrageiras para corte, com e adubação, em Vicosa, Minas Gerais, Rev. Ceres 13 (77): $324-43$. 